\title{
The Imperial Eye
}

\author{
Mark P. Worrell, Daniel Krier
}

\section{| Others and Objects in Jaws}

The figure of the shark in the film Jaws has been compared by Slavoj Žižek to the figure of the mythical Jew in anti-Semitic propaganda: both the shark and the Jew function as an empty signifier that binds together a multitude of analytic or concrete elements and transposes them to a new dimension of synthetic reality (1993: 148-49). To put it in sociological terms: the shark is a name (empty container) that transfers consciousness from the domain of profane stuff (and nominalist empirical operations) into the domain of the sacred, synthetic, sui generis facticity of reified reality. This type of blank object, for Žižek, is part of the Lacanian palette of objects that include the 'signifier of the barred other', the 'object cause of desire' or 'little object a', and the oppressive Thing or Phi object. The shark, the fantasy Jew, etc., are 'monsters' and monsters are blank screens upon which are projected fantasies, fears, etc. In other words, the monster falls under the category of the little object a.

The shark as unobtainable object of desire, the fetish object that causes desire or 'little a', has been discussed by several writers but, as far as we can tell, no one has noticed that the shark in Jaws actually functions differently for each of the main characters in the film such that, for the town sheriff, the shark represents the signifier of the "barred Other'; for the oceanographic expert the shark functions as a completely different object, the classical Thing or "Phi object"; and, of course, for the traumatized boat captain, the shark is the 'object cause of desire' - at this point, the story parallels the whale-captain relation found in Moby Dick.

The 'signifier of the barred Other' is an object that enables a person or group to disavow that the symbolic domain (reality) is inconsistent, that the world really does not make sense, that it is incoherent in many ways and that we are all exposed, every day, to contingency and random occurrences that we do not have control over. Phi objects are obtrusive and overwhelming in their radical over-presence. They represent, in a way, the inverse of the little a in that where the 'little a' is all form and no content, the Phi is all content and no form.

In his analysis of the development of the Hitchcockian cinematic universe Žižek makes the case that each stage of capitalist development supports its own preeminent form of subjectivity: liberal capitalism and the autonomous bourgeois individualist we associate with the Protestant work ethic; imperialist state capitalism (i.e., Fordism) and "the resigned paternal figure" and "organization man"; and finally postindustrial or late capitalism (i.e., post-Fordism) and the "'pathological narcissist', the form of subjectivity that characterizes the so-called 'society of consumption"” where the more we consume the less we 'enjoy' and the more we are punished for failure by insane maternal superego injunctions (1992: 5; 1991: 102-03; see also Worrell and Dangler 2011). The captain, sheriff, and scientist (each from a different generation) fit neatly into this schematic:

\begin{tabular}{|l|l|l|}
\hline Protestant Capitalism & Fordism & Post-Fordism \\
\hline Bourgeois Individualist & Organization Man & Narcissist \\
\hline Boat Captain & Town Sheriff & Scientist \\
\hline Shark = a & Shark = barred A & Shark = Phi \\
\hline
\end{tabular}

One shark is, here, actually three different objects functioning in unique ways for each character.

For the captain of the Orca, the shark represents the illusive object upon which he projects his fantasies and 
desires - a blank screen. After surviving the sinking of the USS Indianapolis that saw much of the crew eaten by sharks, the captain has spent the rest of his life, ostensibly, in pursuit of sharks but it is clear that he is not chasing sharks but the transcendental, imaginary shark. Of course, as Žižek makes clear, we can never (or should never) actually get what we want most and, true to this logic, we find the captain is eaten by the object cause of his desire; when he got to close he was destroyed by it.

For the town sheriff the shark is an administrative problem that threatens to burst not only the town's summer tourist livelihood but also its self-image as pristine American perfection. The presence of the shark reveals that this perfect, small town is actually filled with money-grubbing, cynical, monsters willing to sacrifice human life for money.

For the oceanographic expert the shark is an object that does not fit into the scientific symbolic system. It is a freak. Its presence threatens to burst the established sense of natural objects. Either it would have to be tamed and commodified or must be made to disappear altogether. It is interesting to note that both the scientist and the sheriff have a hand in the ultimate destruction of the animal at the dénouement.

Remaining at the level of ideal types we miss the crucial reality that an object develops from one form to another across time and space. Take for example the figure of Judas as he is transfigured from the gospel of Mark as a somewhat neutral apostle to, finally, in the gospel of John, an incarnation of pure evil - a figure completely at odds with Gnostic interpretations of Judas. Or Jesus himself as a radically different object depending upon the gaze that views him: Roman, Jewish, Christian (orthodox and Gnostic). But here we are not concerned with sharks and old gods but with the dollar.

\section{Magical Capitalism and the Dollar as Object}

Žižek claims that each new capitalist “epoch" is announced by a fresh wave of "monsters" (1992: 139). Fundamental changes in the (symbolic) structure of capitalism generate new imaginary objects that cause desire, mask inconsistencies and represent inert, oppressive remainders of the real. The current unprecedented unleashing of monstrous objects in popular culture, from vampires and werewolves to multi-form zombies (see McNally 2010), can be read as imaginary elaborations of the monstrous power of the dollar. Today, the dollar is readily visible as the ultimate object cause of desire, but what we most wish to draw attention to is the monstrous dimension of the dollar, the dollar as the ultimate, feared builder of empires and destroyer of worlds. The dollar's monstrosity, its destructive presence (where there is a dollar there is death), signals a shift from post-Fordism and the regime of flexible accumulation to something even more horrifying: magical capitalism. While speculative finance capital began to "take flight" under post-Fordism, achieving significant degrees of autonomy and levels of power, exchange-value remained tethered to the organic composition of capital. In magical capitalism, that tether is severed and exchange value is imagined to be entirely liberated from the sphere of the organic composition of capital. The illusion is that value and surplus value can be generated through speculative operations independently of commodity production - e.g., 'speculative' managerial strategies fixated on short-term fluctuations in equities prices (Krier 2005) and other, more exotic maneuvers.

The symbolic and imaginary dimensions of speculative trading in 'magical' capitalism generate an illusion of magical cause and effect in between production of values and speculative activity. What is masked is the real force behind the flight of the dollar: military prowess and the capacity to project terror and fear into world markets. In other words, the destructive dimension of the dollar is not autonomously or magically generated by internal currents in financial markets, but these destructive movements are themselves generated - in whole or in part - by the real destructive force of military weaponry, personnel and organization.

The dollar is not just any money - one of dozens of entirely fungible, entirely exchangeable denominations within the world system. The dollar's unique power derives from the "real" destructive power of the U.S. military that has the power to directly intervene to maintain the dollar's value and destructive power and to shape movements of trading values in global financial and commodity markets from without. The symbolic structure of magical capitalism lacks the signifier for this military power: there is an empty space in the signifying chain that is filled out by imaginary objects.

\section{Three Functions of the Dollar}

The dollar functions differently - is a different object - for various sectors of contemporary capitalist society. 
One of the crucial features of magical capitalism is the permanence of joblessness and high levels of contingent employment in dead-end jobs.

Speculative elites imagine the dollar and its accumulation as a sign of prowess over market forces. Only a magician could command an object that exists everywhere, in multiple dimensions, in this world and also 'behind' it. Money is pure spectral reality at this point. The logic of the dollar represents the command over the spiritual cosmos. Making the correct speculative judgment means that one has successfully manipulated mysterious and unseen forces. Successful speculative accumulation signifies that one has successfully controlled the uncontrollable (comparable to the sheriff in Jaws).

Workers, by contrast, imagine the dollar as not only compensation for a loss of time and energy but as recognition of a job well done, a reward for commitment to the labor contract and their willing obedience to the dictates of capitalist exploitation. The dollar is also that classic fetish screen (little a) upon which their dreams and desires play out. That elusive thing that would bring total satisfaction to all needs and wants (comparable to the captain of the Orca in Jaws).

Deactivated workers and students, marginal types, and the rabble imagine the dollar as the overwhelming Thing that blocks out the sun. Every moment is centered on the lack of the dollar and the desire to draw close to it. Conversely, a character such as the scientist in Jaws represents the marginal type of another order: the over-presence of wealth instead of its lack. He is wealth incarnate (his high-tech exploration vessel was bought with family wealth) and he oscillates between frustrations at the sheriff's lack of sufficient rigidity while, simultaneously, drawn to an abyss just as the boat captain is. The scientist embodies the superimposition of two polar oppositions: anomie and fatalism. So, for the marginal types in society whose marginality is constituted by the lack or insufficient presence of money their world is blotted out by this very lack. On the other side, we find the marginal type embodied by the oceanographic expert whose presence is overwhelming in its very over-enrichment of wealth and who functions as a disruptive blot in both the administrative and bourgeois plane of vision.

\section{Audi and Dystopia}

The Audi automotive brand has an advertisement proclaiming: "The road is not exactly a place of intelligence." The ad features one of its vehicles operating in an urban dystopia of crumbling bridges and decayed infrastructure, incompetent and oblivious drivers and roads littered with debris and junk. The message is clear: we live in a regulative vacuum, society is falling apart, and the only solution is personal, technological and commercial. "Nobody is going to solve this mess" is the message emanating from the voice of the free market - the very thing (or one of the forces) that created the mess.

The Audi commercial is weird in many ways but one way it functions is to deliver the exact opposite of what it explicitly claims. Not only does it claim that the present order is lacking intelligence, but further, that the lack of intelligence, the lack of the transcendental (imaginary) super ego, the total lack of regulation (anomie), decay, dystopia, etc., is in fact intelligent and, in fact, paradise. This automobile was made for these conditions. It is perfection. Why would you want to pull the rug out from under this vehicle thereby depriving yourself of the opportunity to own one? The price of ownership is a depopulated, vacuum-like urban center completely falling apart. People drive around reading their newspaper or simply throwing dilapidated possessions on the side of the highway because there are no negative consequences. What police? What fines? What external gaze exists to judge me? Finally, a paradise of unpunished enjoyment! How can we ensure the actualization of this dystopia so that I may finally, really enjoy life with my new auto?

\section{Empire and Imperialism}

An empire must devitalize its infrastructure due to external, military necessities: U.S. hegemony is real only to the extent that it continues to terrorize the planet for the purpose of keeping the dollar afloat. Our greatest 'export' today is the dollar. When the dollar sinks so does America. Presently, the United States spends as much on the Department of Defense as the rest of the world does on military expenditures combined. Comprehensive estimates that include 
non Department of Defense expenditures place the total annual force cost near one trillion dollars. That money has to come from somewhere and much of it comes at the expense of domestic programs: hyper-exploitation and repression of the internal population result.

\section{Avatar: Dream Like an Empire [1]}

In March 2010, Žižek reviewed Avatar for the New Statesman; his conclusion was that, at its core, the film duplicates a time-honored "reactionary myth" that perpetuates "vampiric exploitation" in the guise of "compassion for the poor." In short, Avatar is racist and brutal in its implications. The film offers up the ideological choice of being "the victim of imperialist reality" or playing the "allotted role in the white man's fantasy." Žižek was more or less correct in his evaluation of the film but he could have gone much further and drawn out many more regressive features. Avatar is important and deserves more attention as it provides, arguably, an ideal-typical expression of what we might think of as the pseudo-progressive consciousness of our time. Avatar gives us an insight into how millions of people can hold two, mutually exclusive sets of values in their minds simultaneously, enabling them to imagine that they are 'liberal' or 'progressive' and 'anti-corporate' while, at the same time, harboring and living out ideas that are reactionary, authoritarian, narcissistic and life-negating.

One of the most obvious and problematic features of Avatar is that it imagines that the solution to the pathological functions of the military industrial complex (MIC) is already found inside the MIC - like a Luther inside the Church who, alone, and driven by ethical purity, can undermine ruthless institutionalized tyranny. Nothing is more fantastic than the notion of an ethically pure trooper who could bring the operations of the MIC to a standstill on the frontier of extraction. We have to do nothing about the MIC because the seeds of its own self-destruction are already festering away, internally. We can go on consuming like mad and burying ourselves in debt because the Department of Defense (DoD) can ultimately purify itself. Indeed, the worse the MIC and we become in our malevolence, the more likely a good change will spontaneously produce itself. Bad capitalism is actually the road to freedom! The worse it is, the better off we will be.

Avatar splits (fetishizes) capital into two separates species: the classic division between productive industrial capital and rapacious, evil capital - here it subsidizes the DoD for the purpose of clearing a path for corporate globalization[2]. In the background is the promise of a return to good, old-fashioned, ethical fair days work for a fair days pay business. If only the evil excess of capital, the MIC-speculation complex could be pacified, then we could get back to the business of good business and the DoD could get back to what it does best: peace-keeping missions and making the world safe for democracy.

A key promise the film makes is that violent revolution is necessary but will happen somewhere else, literally in another world, another time and another place. The mess and destruction of a revolution can be avoided here and now because, evidently, 'here' is a great place, requiring only minor revisions. Revolution should not cost us 'our' world but should come at the expense of the other's world. And if the mass destruction and death involved in revolution is only possible someplace else then it is because it deserves to be purified. Our world is good; the revolutionary battleground, on the other hand, is defective (but naturally perfect) and in need of annihilation. Pointing to the 'speculative identity' of the film, the presence of the evil corporation prefigures the primordial defect of the aboriginals - as if evil capital is forced to appear due to the primitive stupidity of others to get with the program of free market exchange. Of course, what Avatar hides is that our almost perfect world of middle class material sumptuousness is built on top of the other's radical impoverishment and free market exchange. And revolution, while unavoidable, will be postponed for the future - somebody else in the future will have to deal with all this; for now, all we can do is just keep doing what we've been doing.

\section{| Revolution Will Occur Through the Agency of an "Other"}

'Radical' or revolutionary potential is not simply embodied by the white male. The white hero is the embodiment of justice, a gift that he can bestow on others if and when he chooses. However, actual revolutionary action would require a transformation of the white male into a hybrid, alien being (literally inhuman). Revolution is not something 
a decent American (read 'white male') would get involved in. The revolutionary situation is a classic case of the person becoming simultaneously more than and less than his individual form: as a 'sublimate' (his noble and heroic form) must be purchased at the price of assuming a more 'primitive' form; Avatar implies that revolution is not inherently progressive but regressive.

In order to save an environment we should be willing to destroy it in a glorious struggle. We will have to face losing 'the tree' in order to save the tree. And the loss of nature is acceptable because the apparently sui generis 'network' of nature is greater than the tree - loss of finite parts of nature is a trivial price to pay because we need only retain a fraction of the whole in order to preserve the whole itself. The destruction of a key but finite piece of the natural world is bearable because the very loss itself will spontaneously activate its automatic compensation.

One point that Avatar gets right is that sociological altruism (Durkheim) can defeat technology (a lesson that Americans continuously fail to grasp, from Korea, Vietnam, to Afghanistan). But the limits of altruism are reached when war passes over into total war. Avatar slips in petit bourgeois justice as a notion that can suspend even the trump card of total war. We can forge ahead in our purely self-destructive mode (domestically and internationally) without regard for total war and nuclear winter because we are white, right, and full of might - or at least we could be if we wanted to. We can be stopped but even in our 'defeat' we emerge victorious. As always, for Americans, every situation is a 'win-win.' 'This bizarre notion also reinforces the notion that science and technology are inferior to myth, belief and faith. We may have a lot of high-tech gadgets but what will save us, like the 'primitives', is our irrational faith-based society.

Justice in the Avatar world is local (particular) and universalism is inherently evil and corrupt. Forces that penetrate or appear on the boundaries with the particular are only evil and particular communities will always be forced to circle their wagons at the first signs of universalism. Freedom can only be actualized via particular mediation rather than directly and freedom will come at the price of intellectual stagnation and submerging the mind in faith and myth. It is permissible to degrade the earth so long as it was done in good faith and based on faith - in other words, consequences are always mediated by our faith-intention. Our lack of reflexivity is our alibi: of course, had we known what we were doing we would never have done otherwise but since we were misled or duped (a defect of faith) we could not know. The very experience of something like global climate change is proof enough that we were well intentioned, a faithful, good people.

Just as Avatar fetishizes capital it also fetishizes nature. We should be willing to fight to the death for natural resources because they have 'value' as if value were inherent in nature. The film hinges on a naïve realism that ordinary people share with orthodox Marxology: value per se. The film redoubles our misplacement of morality into the natural (amoral) domain. Avatar makes as much sense as evil sharks and Bolshevik ants that populate nature programming. Further, in Avatar we find that some places are sacred and worth dying for; some places are worth the cost of their lives - and, if we lose one or two, it is no big deal since our revolutionary fighter is not even human any more, not one of us.

Avatar also appeals to upper-middle class egoism in that it constructs a morally pure, incorruptible, and noble other for us to project our abstract and impersonal humanitarianism on to - our love of aliens is linked to the inhuman 'brotherly love' of the Calvinist and his de-sublimated descendant, the modern consumer. What Avatar reinforces is the fear of the organized spiritual elite. The film structures revolutionary action along two possible lines: the naturally attuned aliens who are bogged down by the collectivist (horde) mentality and, in the second group, the ethically driven individual; the available options are masses or individuals but not the elite cadre - cadres are for fanatics and terrorists. The good (and imaginary) fight just needs one 'activist' or good guy (with a little good luck thrown in along with common sense and a dash of moral indignation) to mobilize the masses. One could easily see in this fantasy not just narcissism but full-blown psychosis. And since in this arrangement everybody in the category of 'mass' would have to agree to follow the singular leader, and since that is impossible, it means that actual revolution would have to remain forever in the domain of fantasy. Either we all pull together or nothing is possible. I'm not going to risk my life unless everybody is willing to die for my adventure. The Avatar fantasy also says a lot about the uniquely American conception of self-sacrifice.

Self-sacrifice, here, is a form of degraded utilitarianism. The hero who sacrifices his self actually gains much more: regaining the full use of a (now alien) body: sacrifice is only worth it so long as I get a lot more out of it and do not actually lose my life. Revolutionaries qualify for a life upgrade upon completion of the mission. Sacrifice in Avatar follows an all-or-nothing logic: either I will save the whole world or I'll just stay at home and do nothing. Mundane, simple forms of everyday assistance are too boring and trivial to imagine. It is easier and more fun to imagine my body transformed into an alien who defeats the combined forces of evil capital and have unlimited 
sexual relations with a princess than it is to just do something small but potentially helpful to concrete people with actual needs. For Avatar fans, the revolution will have to be mightily entertaining and rewarding for them to get interested. Since that will never happen, they will do nothing. Avatar is a film that negates the tensions it conjures up and paralyzes its audience - the negation of the negation is already retroactively posited in the original act of the purchase of the ticket. Futility here, as with the voting booth, is seemingly dissolved but preserved in spectacle.

\section{James Bond Viewed Through the Imperial Eye}

James Bond, the fictional British Secret Service agent created by Ian Fleming in the 1950s, has appeared in more than 23 films and has become an icon of Western Imperialism. Bond's cultural significance is on vivid display in 2012, with museum exhibitions, film retrospectives and much media commentary marking the 50th anniversary of the film franchise. Much of this attention has been focused upon the moments when new actors were cast into the role, altering the character's screen persona. We argue that major transformations in the structure of capitalism are announced not only by new monsters, but also by new actors playing James Bond.

The most recent actor to play the role, Daniel Craig (Casino Royale 2006; Quantum of Solace 2008; Skyfall 2012), portrays him as a cold, ascetic soldierly-male. While there are many continuities between Craig's Bond and those of his predecessors, the screen persona he generates marks a significant departure. Compared to Craig, earlier Bonds appear as hairy-knuckled, cheek-slapping lechers; blow-dried, leisure-suited, creaky playboys or over-pretty, politically-correct, randy poseurs -- all guns and hair-goo. Craig's Bond hardly requires a gun (and would never use hair-goo), preferring hot and sweaty kills with bare hands at extreme close range. Craig's Bond has revitalized a bewhiskered franchise, receiving accolades from film critics and record revenues from contemporary audiences.

Craig's Bond resulted from intentional "rebooting" of the Bond marquee. Bond films typically deployed title sequences with scantily clad, undulating women in silhouette. In contrast, the title sequence to 2006's Casino Royale replaced soft, curvy women with hard-edged men killing other men in an orgy of blood. The theme song for the film featured the refrain "the coldest blood runs through my veins." Craig's Bond preferred to kill men with his hands rather than touch women with them. Man-on-man fight scenes were staged and filmed like love scenes. The camera lingered upon intimate gyrations that ended in blackout or death: a "negative orgasm" in the terms of Klaus Theweleit (1989). Craig's Bond films depicted an erotics of destruction rather than an erotics of intimate, sexual love. Such erotics of destruction features in other recent imperialist-themed films. Whereas the classic film spy or warrior killed enemies of empire as a duty-bound, sublimated fulfillment of symbolic mandates (i.e. a job), more recent cinematic spies and warriors clearly "get off" on killing. Unable to find jouissance in love relationships, Craig's Bond found it in painful, punishing struggle with other men.

While earlier film Bonds were knowledgeable about large-scale politics, strategic concerns and ideology, Craig's Bond cared little for such matters. He wanted a fight and was indifferent to the identity of his opponents (he beat comrades and enemy combatants with equal intensity). The fight was an end-in-itself rather than a means to a larger end.

Craig's Bond was emotionally-detached. His closest interpersonal relationship was a particularly troubled one with the mother-surrogate, "M," head of the secret service that employed him. The dyadic relationship between Bond and " $\mathrm{M}$ " was characterized by ongoing fantasy-riddled struggles of separation, individuation, engulfment and abandonment (e.g. multiple violations of the other's personal boundaries: breaking in to each other's homes, using each other's passcodes to spy upon each other surreptitiously, etc.). Craig's Bond was depicted as someone who avoided, resisted or remained immune from the need for object relations. Almost all previous Bond films ended with the "production of a romantic couple," but all three of Craig's films end with Bond unattached to a love object. If love objects were not central to Craig's Bond, what structures the psychic universe of these films?

Another defining trait of Craig's Bond was his attraction to and temporary involvement with "unavailable" women (those married to other men or those who aggressively rejected his advances). Interestingly, the five women with whom he had physical contact in the three films died shortly afterwards. While earlier Bonds were noted for voracious sexual appetites and promiscuity, Craig's Bond displayed dampened sexual desire (reviews of the first two Craig Bond films have been described as "chaste"). What remained of the character was a killer who searched, even cruised, for opportunities for close, physical and deadly combat with other men like himself. Indeed, Craig's Bond faced antagonists who were "doubles" of Bond himself: enemies whose physical appearance, style of dress, and 
character structure mirrored those of Bond: gym-obsessed, militarized, hardened killers.

Perhaps the trait that most strikingly departs from previous cinematic portrayals of Bond was the extreme levels of physical fitness and destructive physicality that Craig displayed on screen. Earlier film Bonds were gentlemanly "fit" rather than over-muscular or "buff." Many other mid-20th century imperialist-themed heroes (played by men like Humphrey Bogart, James Stewart or John Wayne) diverged even further from masculine physical ideals. Consider the shirtless, jiggly belly of George C. Scott as hawkish cold-warrior General Buck Turgidson in Stanley Kubrick's (1964) Dr. Strangelove. Craig's Bond, in contrast, looked as though he could kill someone (an explicit goal of his training regime), and his appearance evoked painful workouts and ascetic regulation of nutrition. The musculature of Craig was not ornamental, like steroid-inflated bulk on 1980s action stars, but hard, lean and functional. Such extreme levels of physical fitness - what Theweleit (1989) labels "body armoring - became widespread in contemporary imperialist-themed films (including Avatar, Apocalypto to name just two).

The asceticism necessary to maintain armored musculature shades off into masochism, the final trait of Craig's Bond. The tableau scene of Casino Royale (2006) was a particularly brutal torture scene in which Craig's Bond was stripped, tied to a bottomless chair and beaten repeatedly on his exposed genitals until he blacked out. Craig's Bond not only endured the beating, but also egged on his torturer, jokingly feigning (or not?) enjoyment of the beating. While many film commentators have drawn attention to the sadism of James Bond, few have noted the masochism that was always present, but brought to the fore with Craig, not only in the depiction of genital-punishment, but also with the frequent loss of reputation, social honor, and humiliation that occurs in the film at the hands of his boss and colleagues.

The capacity to stand firm and take punishment (ascetic discipline) is closely related to masochistic enjoyment of pain, humiliation and punishment. This is drawn out in one recent parody of the James Bond films, Rowan Atkinson's Johnny English, Reborn (2011). In this film, Johnny English, a lapsed secret service agent, is undergoing warrior training in Tibet in the hopes of regaining appointment to MI6. The "training" is mostly centered upon the genitalia: the warriors-to-be kick each other in the groin and drag progressively heavier stones tied to their genitals. The theme is clear: in order to be a warrior, one must deaden the genitalia. And the film's plot does indeed hinge upon the 007 prototype's capacity to cheerfully sustain repeated blows to the nether regions, to stand firm under such attack.

The toned, muscular body of recent imperialist films signifies submission to a masochistic regime of suffering. Such extreme levels of muscular development and physical fitness is impossible to obtain without hours of discomfort, muscular toil, joint pain, ascetic avoidance of calories, leisure and sedentary pleasures. To display such a body is to submit to systematic body-shaping and dietary restrictions as a central organizing principle of existence.

James Bond: The Soldierly-Male

Readers of critical theory may find the character portrait of Craig's Bond - wounded, suffering, yet armored - eerily familiar. We have seen this character-type before in Klaus Theweleit's Male Fantasies (1987; 1989) an analysis of the ideal-type "soldierly-male" of the interwar years in Germany. The men that Theweleit studied were former members of the Freikorp: volunteer proto-fascist militia who fought deadly civil-war battles with socialists, communists and workers in the very early years of the Weimar Republic. Like Craig's Bond, these men had a clear preference for male bonding in warfare rather than domestic intimacy with women: "movement toward soldiering" is "movement away from women" (Theweleit 1987: 29). Women were split into all-good mother-sister-virgin figures who were neither physically present nor sexually-available to them and all-bad "red women," who were destabilizing and violently fended off to protect against the threat of intimacy. The language used by these men did not objectify the women (making them sexual objects), but de-animated women as things devoid of life. Pleasure for these men came from destruction, killing and warfare: "vengeance" against an enemy not sexual contact with a lover (Theweleit 1987: 34). They focused their energy and interpersonal activity upon building disciplined bodies and armored selves that could be arranged into a defensive structure, a macro-machine of militarized soldier-males in tight formation.

Craig's Bond stages with clarity the incompatibility of imperial soldiering and loving object relations. Like the men Theweleit analyzes, Craig's Bond avoided romantic love, erotic desire and sexual enjoyment since these threatened to disintegrate their defenses. The armored body boundaries of such men were beaten onto them (by others and by the self) and was maintained by close contact (tight formation) with similarly armored bodies of other soldierly-males. The jouissance accorded to such men was located in pleasurable discharge in destructive violence. Imperial armies have long been composed of such men. Empires are maintained by soldiers whose primary pleasures come from soldiering. They bond with other soldiers, escape the pressures of civilian life - especially civilian love life. They release destructive energy in acts of violence against dehumanized or at least de-animated enemies. Craig's 
Bond depicted the central incompatibility of soldierly-males and "normal" object relations: love relationships with a woman (Vesper Lynd in Casino Royale) require resignation from military service. Like Theweleit's soldierly-males, the jouissance of Craig's Bond is bound up with in soldiering for Her Majesty's Secret Service rather than in simple domestic pleasures. And so, the love object must die so that Bond can return to the work of killing for the empire.

\section{Avatar, Empire and the Doubled Soldierly-Male}

We now return to the analysis of Avatar, a film that went even further than Craig's Bond at staging the "armoring" of soldierly-males. Avatar, like the Batman films, the Empire Strikes Back and the Matrix trilogy - depicted soldiers putting on body armor composed of different materials. The soldier in Avatar was like a Russian doll. First, the soldier obtained musculature through the armoring processes described by Theweleit: drilling, exercising, painful punishment of the body, etc. Then the soldier put on light protective clothing and finally, climbed inside of an exoskeleton, an external metallic body armor that enhanced the soldier's capabilities to withstand attack and to unleash destructive violence. The device, referred to in the film as an AMP (amplified mobility platform) allowed the soldierly male to magically realize their ideal. Soldiers immersed in these armoring devices had massive arms and legs, but no head (they look similar to Robert Minor's early 20th century cartoon of the "perfect soldier"). They also had no genitals. As such, they were perfect components of a disciplined macro-machine (ego-control of behavior and genitally-generated desire are missing, hence nothing to disrupt the execution of orders).

In Avatar, Theweleit's soldierly-male was doubled into two split-off forms of armored body. The older, ultrabutch Colonel Quaritch was armored with the technical, metallic, acephalous and castrated AMP while the young, soft and already-crippled (castrated) Jake Sully was armored with the biological body of his Na'vi avatar. Sully, inside of his armored avatar body, went through rigorous boot camp training at the hands of the beautiful native princess, transforming himself into the toughest warrior in the forest, defeating all actual natives. Sully's young blue-bodied soldierly-male became supple, sexually potent and capable of intimate surrender, love and commitment while his split-off double, Colonel Quaritch, remained a classic killing machine in the pattern outlined by Theweleit.

The Colonel's mechanical exoskeleton was complete with bionic, metallic extensions and advanced, integrated weaponry. The price of this armor, like the price for Theweleit's soldiers, was the surrender of intimate object relations. This sacrifice was apparent in the imagery of the MIC headquarters in Avatar. Truly a military-industrial complex, the set design incorporated an almost perfect fusion of military and corporate aesthetic. Mod furniture and anonymous artwork that one normally sees in corporate offices are minimized. Medals, trophies and other honorific insignia of the military are also minimized: no parade grounds, medals, dress uniforms, etc. Inside the exoskeleton or outside of it, the Colonel functioned as a one-sided, abusive drill sergeant rather than an officer. All remnants of gentile, honorific conduct or the habitus of chivalry linked to larger social values were absent from his character.

Colonel Quaritch came very close to realizing a pure form of the soldierly-male constructed by Theweleit. He engaged in weight lifting and other tough exercise to keep himself hard: "You get soft, Pandora will shit you out dead with zero warning," he tells Sully in their first meeting and orders his subordinates to develop a tough mental attitude. He deployed the imagery of standing firm, forming a defensive barrier or wall, not allowing a breach, in other words, finding safety and security through attachment to a disciplined formation. He feared the "mire," "mud" and ooze: "Out there, beyond that fence, every living thing that crawls, flies or squats in the mud wants to kill you and eat your eyes for jujubes." He expressed fear of being overrun, he wanted missions "high and tight:" the heights were safe while "down there" was danger.

The Colonel manifested dogmatic, black and white thinking. He remorselessly punished those who "crossed the line" in disobedience. He was indifferent to larger strategic or profit motives of the corporation or the values of the larger society. Instead, his desired killing for its own sake, relished opportunities to "get off" on the unleashing of destructive violence. He used language and adopted attitudes that "derealized" the reality of killing. He displayed inappropriate emotion and manifested a decided lack of empathy. The Colonel drank coffee while killing Na'vi, he downplayed the reality of what was actually happening by dramatically understating the consequences of actions. He remained emotionally detached -- "that's how you scatter the roaches" he announced after fire-bombing natives. Throughout the film, the Colonel was entirely devoid of sexual talk or action. In fact, no one within the Hells' Gate compound on Pandora was depicted within an intimate relationship nor were they desirous of sex. The MIC was strangely and entirely desexualized: the MIC administrators, the soldiers, even the "liberal" scientists lacked genital 
desire.

Like other imperial-themed films, Avatar depicted the military as a magic agency that could transform young boys with puny, soft "boy bodies" into large, muscular, hardened armored beings. The exoskeletons were merely the imaginary representation of the muscular armoring that was already ignited in fantasy. Though sexless, Avatar depicted an imperial military as a site of immense destructive pleasure. One not only was able to develop a powerful exoskeleton, but one had the enjoyment of unleashing its fury in violent battle.

Theweleit's soldierly-men were vividly aware of the impossibility of simultaneously fulfilling the symbolic mandate of the imperial military and that of domestic civilian life. They were aware of the impossibility of being both an imperial soldier and a domestic spouse or parent. The soldier-male was perpetually absent from home, perpetually at risk of injury or death, maintained close ties to and companionship with other soldiers. The characterstructure that found jouissance in such a life was inconsistent with the character-structure that found jouissance thorough intimate love relations, daily presence as a contributor to family life and household economy. Avatar did not confront this symbolic impossibility head-on, but masked it by staging the fantasy that one could have it both ways, that the inconsistencies of the system were somehow mediated through Sully's adoption of the supple, sexually-potent, loving native who is also an armored destructive warrior.

Imperialism should be the master signifier of contemporary magic capitalism, the location of the quilting point that fixes the meaning of all other signifiers. But, in fact, imperialism is a word that rarely appears in contemporary discourse - a symbol that is strangely missing given its obvious signifying power. But then capitalism does not function by overtly providing symbols and concepts that reveal its actual functioning but rather, as Žižek has made clear, operates by masking and obscuring the gaps in the system with "sublime objects" that paste over the holes in the symbolic order - providing not only the appearance of completeness, but more importantly, generating a user's illusion that launches the action necessary to keep the system circulating.

The popularity and appeal of imaginary productions like Craig's Bond and Avatar tell us much about the location of the gaps in the symbolic order. They identify the place of its radical incommensurability, the jarring inconsistencies that most need masking. These imaginary productions maintain the illusion of consistency that enables contemporary magical capitalism and its hidden military support to continue.

In his "Cult of Distraction" Kracauer makes an extremely valuable point when it comes to films that paralyze audiences: "the very fact that the shows aiming at distraction are composed of the same mixture of externalities as the world of the urban masses; the fact that these shows lack any authentic and materially motivated coherence, except possibly the glue of sentimentality, which covers up this lack but only in order to make it all the more visible; the fact that these shows convey precisely and openly to thousands of eyes and ears the disorder of society - this is precisely what would enable them to evoke and maintain the tension that must precede the inevitable and radical change. In the streets of Berlin, one is often struck by the momentary insight that someday all this will suddenly burst apart. The entertainment to which the general public throngs ought to produce the same effect" (1995).

\section{Endnotes}

1. The material on Avatar took initial form in "The Inner Logic of Avatar" by Worrell in New Politics, Vol. 52 (2012). 


\section{References}

Amidon, Kevin and Dan Krier. 2009. "On Rereading Klaus Theweleit's Male Fantasies." Men and Masculinities. Volume 11: No. 4 (June): 488-496.

Kracauer, Siegfried. 1995. The Mass Ornament. Cambridge: Harvard University Press.

Krier, Dan. 2005. Speculative Management: Stock Market Power and Corporate Change. Albany: State University of New York Press.

McNally, David. 2011 Monsters of the Market. Brill: Leiden and Boston.

Theweleit, Klaus. 1987. Male Fantasies, Vol. 1: Women, Floods, Bodies, History. University of Minnesota Press: Minneapolis.

-----. 1989. Male Fantasies, Vol. 2: Male Bodies: Psychoanalyzing the White Terror. University of Minnesota Press: Minneapolis.
Worrell, Mark. 2009. Dialectic of Solidarity. Chicago: Haymarket.

-----. 2012 “The Inner Logic of Avatar.” New Politics 52: (http:// newpol.org/content/inner-logic-avatar).

Worrell, Mark and Jamie Dangler. 2011. "Café Narcissism Redux." Pp. 72-92 in Journal of No Illusions: Telos, Paul Piccone, and the Americanization of Critical Theory, edited by Ben Agger and Tim Luke. New York: Telos Press.

Žižek, Slavoj (ed). 1992. Everything You Always Wanted to Know about Lacan (But Were Afraid to Ask Hitchcock). London and New York: Verso.

-..-.. 1993. Tarrying with the Negative. Durham: Duke University Press. 